\title{
Определение пигментного состава зерен ячменя при помощи сверточных нейронных сетей
}

\author{
Артеменко Н.В. ${ }^{1}$, Бусов И.Д. ${ }^{1}$, Заварзин Е.А. ${ }^{1 *}$, Ивлева А.И. ${ }^{3}$, Кожекин М.В. ${ }^{1,2}$, \\ Глаголева А.Ю. ${ }^{2}$, Генаев К.А. ${ }^{4}$, Генаев М.А. ${ }^{1,2}$, Коваль В.С. ${ }^{2}$, Комышев Е.Г. ${ }^{1,2}$ \\ ${ }^{1}$ Новосибирский государственный университет, Новосибирск, Россия \\ ${ }^{2}$ Институт ичтологии и генетики СО РАН, Новосибирск, Россия \\ ${ }^{3}$ Самарский федеральный исследовательский ичентр РАН, Институт проблем управления \\ сложными системами РАН, Самара, Россия \\ ${ }^{4}$ Expasoft, Новосибирск, Россия \\ *zavarzinevg@gmail.com
}

Ключевые слова: ячмень, зерна, феномика, компьютерное зрение, обработка изображений, нейронные сети, CNN, сегментация, классификация

Мотивациия и цุель: Наличие или отсутствие пигментов, а именно меланина или антоциана, в оболочках зерен ячменя влияет на их технологические и функциональные свойства, которые важны для промышленного применения и для потребителя. Существующие методы решения этой задачи обладают рядом недостатков, таких как субъективность, большая стоимость, трудозатратность, времязатратность и, как следствие, невозможность исследовать большое количество образцов. В нашем проекте реализуется альтернативный метод определения содержания антоцианов и меланинов в оболочке зерен ячменя, который основан на анализе двухмерных изображений, полученных цифровыми камерами.

Meтоды $и$ алгоритмы: В работе используются фотографии зерен ячменя, разложенных на чашке Петри. Для решения задач сегментации, а также классификации использовались сверточные нейронные сети на основе архитектуры Unet [1]. Также для задачи классификации использовался алгоритм Random Forest. Метрика сегментации - IoU. Метрика классификации - accuracy. Результаты: Наибольшую точность из полученных моделей показала сверточная сеть сегментации с головой для классификации (Unet with head [2]). Модель сегментирует изображение на два слоя: зёрна и фон. Голова классификации при этом определяет пигментацию зерен на изображении. Аccuracy модели составляет $95.6 \%$.

Благодарности: Материал был получен из коллекции ячменя Всероссийского института генетических ресурсов растений имени Н.И. Вавилова.

Список литературы

1. Ronneberger $\mathrm{O}$. et al. U-net: Convolutional networks for biomedical image segmentation. 2015; arXiv preprint arXiv:1505.04597.

2. Yakubovskiy P. Segmentation Models Pytorch\}. GitHub repository https://github.com/qubvel/segmentation_models.pytorch 